\title{
Reviews and syntheses: Trends in primary production in the Bay of Bengal - is it at a tipping point?
}

\author{
Carolin R. Löscher \\ Nordcee, DIAS, Department of Biology, University of Southern Denmark, Campusvej 55, 5230 Odense M, Denmark
}

Correspondence: Carolin R. Löscher (cloescher@biology.sdu.dk)

Received: 15 January 2021 - Discussion started: 26 January 2021

Revised: 13 July 2021 - Accepted: 20 July 2021 - Published: 13 September 2021

\begin{abstract}
Ocean primary production is the basis of the marine food web, sustaining life in the ocean via photosynthesis, and removing carbon dioxide from the atmosphere. Recently, a small but significant decrease in global marine primary production has been reported based on ocean color data, which was mostly ascribed to decreases in primary production in the northern Indian Ocean, particularly in the Bay of Bengal.

Available reports on primary production from the Bay of Bengal (BoB) are limited, and due to their spatial and temporal variability difficult to interpret. Primary production in the BoB has historically been described to be driven by diatom and chlorophyte clades, while only more recent datasets also show an abundance of smaller cyanobacterial primary producers visually difficult to detect. The different character of the available datasets, i.e., direct counts, metagenomic and biogeochemical data, and satellite-based ocean color observations, make it difficult to derive a consistent pattern. However, making use of the most highly resolved dataset based on satellite imaging, a shift in community composition of primary producers is visible in the $\mathrm{BoB}$ over the last 2 decades. This shift is driven by a decrease in chlorophyte abundance and a coinciding increase in cyanobacterial abundance, despite stable concentrations of total chlorophyll. A similar but somewhat weaker trend is visible in the Arabian Sea, where satellite imaging points towards decreasing abundances of chlorophytes in the north and increasing abundances of cyanobacteria in the eastern parts. Statistical analysis indicated a correlation of this community change in the $\mathrm{BoB}$ to decreasing nitrate concentrations, which may provide an explanation for both the decrease in eukaryotic nitratedependent primary producers and the increase in small unicellular cyanobacteria related to Prochlorococcus, which have a comparably higher affinity to nitrate. Changes in com-
\end{abstract}

munity composition of primary producers and an overall decrease in system productivity would strongly impact oxygen concentrations of the BoB's low-oxygen intermediate waters. Assuming decreasing nitrate concentrations and concurrent decreasing biomass production, export, and respiration, oxygen concentrations within the oxygen minimum zone would not be expected to further decrease. This effect could be enhanced by stronger stratification as a result of future warming and thus possibly counteract oxygen decrease as a direct effect of stratification. Therefore, given a decrease in primary production, the BoB may not be at a tipping point for becoming anoxic, unless external nutrient inputs increase.

\section{The role of the Bay of Bengal in primary production in the global ocean - a historical perspective}

Marine primary producers contribute around $50 \%$ to global net primary production (Behrenfeld et al., 2001), leading to a carbon flux from the atmosphere into the ocean of 45-50 $\mathrm{PgC}$ and up to $90 \mathrm{Pg} \mathrm{C} \mathrm{yr}^{-1}$ (Longhurst et al., 1995; Sabine et al., 2004; Sarmiento and Gruber, 2002). Changes in ocean primary production exert an important control on atmospheric carbon dioxide $\left(\mathrm{CO}_{2}\right)$ concentrations, and thus on global climate (Falkowski et al., 1998). The BoB has often been described as an area of low primary production compared to the Arabian Sea. This low productivity has classically been ascribed to a strongly stratified water column as a result of increased surface water temperatures (Kumar et al., 2004) in combination with lowered surface water salinity due to monsoon-governed episodes of massive rainfall and river discharge with maximum freshwater inputs in September (e.g., Mahadevan, 2016). The stratification extends through 


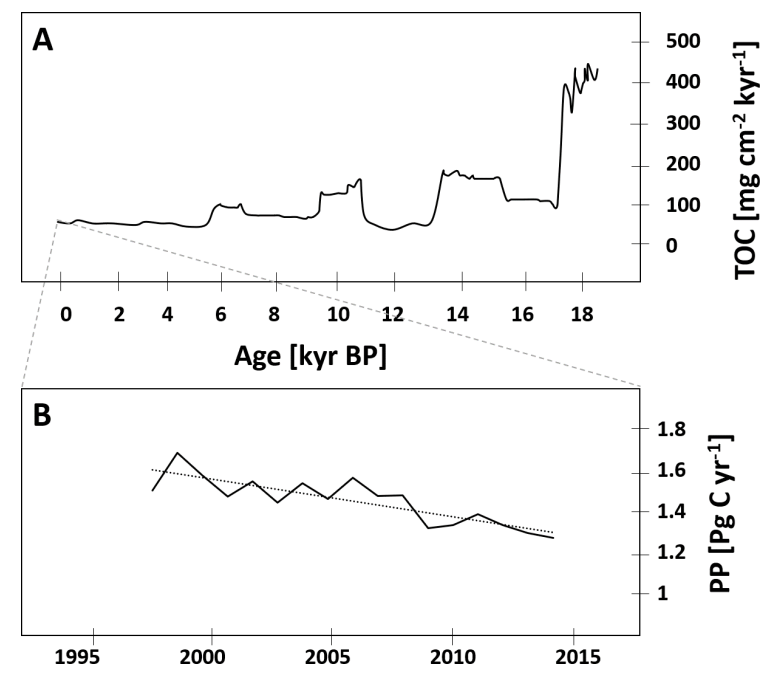

Figure 1. (a) Trends or total organic carbon (TOC) in the sediment record over the last $18 \mathrm{kyr}$ before present adapted from ContrerasRosales et al. (2016), and (b) modeled decrease in primary production between 1998 and 2014 modified from Gregg and Rousseaux (2019).

large parts of the BoB basin (Subramanian, 1993), restricting nutrient fluxes to the surface and eventually limiting primary production. In coastal areas, nutrient inputs from the major rivers have been described to stimulate primary production; however, rapid consumption as well as a ballasting effect with lithogenic particles and subsequent sedimentation of organic matter prevent offshore transport (Singh et al., 2012; Singh and Ramesh, 2011; Krishna et al., 2016; Kumar et al., 2004; Ittekkot, 1993). Open waters therefore appear low in macronutrients, exhibiting a slight nitrogen undersaturation at least temporarily (Bristow et al., 2017; Löscher et al., 2020). However, nitrogen fixation has been described as low to non-existent (Saxena et al., 2020; Löscher et al., 2020), therefore not compensating for the nitrogen deficit. The available geological record suggests that nitrogen fixation is generally absent since the last glacial maximum where isotope records showed an enrichment in ${ }^{15} \mathrm{~N}$ indicative of nitrogen fixation (Contreras-Rosales et al., 2016; Shetye et al., 2014; Dähnke and Thamdrup, 2013). Corresponding to this absence of $\mathrm{N}_{2}$ fixation, low primary production is suggested from deep time records of total organic carbon (TOC, Fig. 1a) on a timescale of $18 \mathrm{kyr}$ before present (BP).

While a decrease in primary production has been derived in models for the last decades (Fig. 1b; Gregg and Rousseaux, 2019; Roxy et al., 2016) in the Indian Ocean, shorter historical records of primary production in the $\mathrm{BoB}$ are not too abundant. However, records of direct rate measurements go back to the RV Galathea and RV Anton Bruun expeditions in the early 1950s, followed by the International Indian Ocean Expedition (IIOE) from 1959 to 1965 (Snider, 1961). Those earliest records report primary produc- tion of $0.1-2.16 \mathrm{mg} \mathrm{C} \mathrm{m}^{-2} \mathrm{~d}^{-1}$ for the shelf regions and 0.1$0.3 \mathrm{mg} \mathrm{C} \mathrm{m}^{-2} \mathrm{~d}^{-1}$ for open ocean waters of the BoB. Comparably higher rates were reported from an expedition with the Russian RV Vityaz from 1956 to 1960, with rates between 70 and $3600 \mathrm{mg} \mathrm{C} \mathrm{m}^{-2} \mathrm{~d}^{-1}$, from a record from 1970 with a rate of $190 \mathrm{mg} \mathrm{C} \mathrm{m}^{-2} \mathrm{~d}^{-1}$ (Nair et al., 1973), and from a summer monsoon situation in August-September 1976 with rates between 130 and $330 \mathrm{mg} \mathrm{C} \mathrm{m}^{-2} \mathrm{~d}^{-1}$ (Radhakrishna et al., 1978). Some of those earlier measurements were suggested to be biased as a result of trace metal contamination before trace metal clean techniques were available, a problem identified by calculating primary production to chlorophyll ratios, which turned out to be extremely high (2502500 compared to an average of $23 \pm 13$ in later data presented in Table 1; Madhupratap et al., 2003). Later reports show a high variability of primary production ranging between 0.3 and $936 \mathrm{mg} \mathrm{C} \mathrm{m}^{-2} \mathrm{~d}^{-1}$ (Gomes et al., 2000; Murty et al., 2000; Balachandran et al., 2008; Madhupratap et al., 2003; Gauns et al., 2005; Kumar et al., 2010, 2004; Mohanty et al., 2014; Subha Anand et al., 2017; Löscher et al., 2020; Jyothibabu et al., 2004; Madhu et al., 2006; Muraleedharan et al., 2007; Prasanna Kumar et al., 2002; Sarma et al., 2020; Saxena et al., 2020; Singh et al., 2015) and extremes of $2200 \mathrm{mg} \mathrm{C} \mathrm{m}^{-2} \mathrm{~d}^{-1}$ (Bhattathiri et al., 1980), with generally higher rates in shelf regions compared to the open ocean, which were combined into average rates of 500 and $300 \mathrm{mg} \mathrm{m}^{-2} \mathrm{~d}^{-1}$ for shelf and open ocean, respectively, to obtain a carbon flux budget (Naqvi et al., 2010). These average rates are quantitatively comparable to the studies presented in Table 1; however, for instance mesoscale water mass dynamics have been observed to promote primary production in the $\mathrm{BoB}$ beyond those ranges up to $920 \mathrm{mg} \mathrm{C} \mathrm{m}^{-2} \mathrm{~d}^{-1}$, likely because of eddy-related decreases in stratification and pumping of nutrients into otherwise nutrient-exhausted photic surface waters (Sarma and Udaya Bhaskar, 2018). Direct assessments of primary production in eddies of the $\mathrm{BoB}$ showed an increase in primary production and surface chlorophyll concentrations due to eddy-related nutrient pumping (Singh et al., 2015; Sarma et al., 2020), with increased primary production being associated with diatom blooms (Vidya and Prasanna Kumar, 2013). Eddies and other mesoscale and sub-mesoscale dynamics are frequent in the BoB (Cui et al., 2016; Greaser et al., 2020; Dandapat and Chakraborty, 2016; Vimal Kumar et al., 2016) and therefore may cause significant variation in primary production patterns. Additional variation results from the strong influence of the two monsoon-governed seasons on primary production (Gomes et al., 2000; Jyothibabu et al., 2018; Madhu et al., 2002; Gauns et al., 2005; Table 1). Based on the presented data, a current estimate of primary production would be in the range of $361 \pm 145$ and $236 \pm 121 \mathrm{mg} \mathrm{C} \mathrm{m}^{-2} \mathrm{~d}^{-1}$ for coastal and open ocean regions, respectively, which is 1 order of magnitude below the Arabian Sea, depending on the region and time of the year (Naqvi et al., 2010). 
Table 1. Historical record of water-column-integrated chlorophyll $a$ concentration, surface chlorophyll $a$ concentration, and primary production.

\begin{tabular}{|c|c|c|c|c|c|c|}
\hline Year & Month & Season & $\begin{array}{l}\text { water column integrated } \\
\operatorname{chl} a\left(\mathrm{mg} \mathrm{m}^{-2}\right)\end{array}$ & $\begin{array}{l}\text { Surface chl } a \\
\left(\mathrm{mg} \mathrm{m}^{-3}\right)\end{array}$ & $\begin{array}{l}\text { Primary production } \\
\left(\mathrm{mg} \mathrm{C} \mathrm{m}^{-2} \mathrm{~d}^{-1}\right)\end{array}$ & Reference \\
\hline 1951 & & & & & $0.1-2.16$ & $\begin{array}{l}\text { Galathea and Anton Brunn } \\
\text { expedition, } \\
\text { Nielsen and Jensen (1957) }\end{array}$ \\
\hline 1956 & & & & & 70 to 3600 & RV Vityaz in 1956-1960 \\
\hline 1961 & & & & & 190 & Nair (1970) \\
\hline 1976 & & Summer monsoon & $8.63-28.45$ & $0.084-1.67$ & $129.99-329.49$ & Rhadakrishna et al. (1978) \\
\hline 1977 & & Summer monsoon & $2.11-33.72$ & $0.03-1.04$ & & Devassy et al. (1983) \\
\hline 1978 & August & Summer monsoon & $\begin{array}{l}1.28-33.72 \\
\text { (up to } 50 \text { ) }\end{array}$ & $0.01-1.01$ & $180-2200$ & Bhattahiri et al. (1980) \\
\hline 1996 & May-June & Summer monsoon & & $0.01-0.2$ & & Murty et al. (2000) \\
\hline 1996 & April-May & Spring intermonsoon & up to 53 & & 4.5 & Gomes et al. (2000) \\
\hline 1996 & & Summer monsoon & up to 92 & & 0.3 & Gomes et al. (2000) \\
\hline 2000 & July-August & Summer monsoon & & & $\begin{array}{l}\text { coastal: } 350 \pm 225 \\
\text { oceanic: } 251 \pm 177\end{array}$ & Madhu et al. (2006) \\
\hline 2000 & $\begin{array}{l}\text { November- } \\
\text { December }\end{array}$ & Winter monsoon & & $9.0-15$ & $87-187$ & Balachandran et al. (2008) \\
\hline 2000 & December & Winter monsoon & & & $\begin{array}{l}\text { coastal: } 252 \pm 210 \\
\text { oceanic: } 231 \pm 150\end{array}$ & Madhu et al. (2006) \\
\hline 2001 & $\begin{array}{l}\text { November- } \\
\text { December }\end{array}$ & Winter monsoon & $\begin{array}{l}\text { coastal: } 7-23 \\
\text { oceanic: } 8-18\end{array}$ & $\begin{array}{l}\text { coastal: } 0.06-0.16 \\
\text { oceanic: } 0.06-0.28\end{array}$ & $\begin{array}{l}\text { coastal: } 253-566 \\
\text { oceanic: } 99-423\end{array}$ & $\begin{array}{l}\text { Gauns et al. (2005) } \\
\text { Madhupratap et al. (2003) }\end{array}$ \\
\hline 2001 & July-August & Summer monsoon & $\begin{array}{l}\text { coastal: } 12-19 \\
\text { oceanic: } 10-11\end{array}$ & & $\begin{array}{l}\text { coastal: } 40-502 \\
\text { oceanic: } 89-221\end{array}$ & Gauns et al. (2005) \\
\hline 2002 & April & Spring intermonsoon & & & $\begin{array}{l}\text { coastal: } 308 \pm 120 \\
\text { oceanic: } 303 \pm 95\end{array}$ & Madhu et al. (2006) \\
\hline 2002 & April-May & Spring intermonsoon & & $0.25-0.4$ & & Kumar et al. (2010) \\
\hline 2002 & $\begin{array}{l}\text { September- } \\
\text { October }\end{array}$ & Intermonsoon & $\begin{array}{l}\text { coastal: } 11-19 \\
\text { oceanic: } 13-16\end{array}$ & & $\begin{array}{l}\text { coastal: } 250-469 \\
\text { oceanic: } 202-427\end{array}$ & Gauns et al. (2005) \\
\hline 2002 & $\begin{array}{l}\text { November- } \\
\text { December }\end{array}$ & Winter monsoon & $\begin{array}{l}\text { coastal: } 9-15 \\
\text { oceanic: } 9-13\end{array}$ & & $\begin{array}{l}\text { coastal: } 115-187 \\
\text { oceanic: } 87-164\end{array}$ & Jyothibabu et al. (2004) \\
\hline 2003 & April-May & Pre-monsoon & & & $\begin{array}{l}\text { 154-975 (average coastal: } 552 \text {, } \\
\text { average oceanic: } 284 \text { ) }\end{array}$ & Kumar et al. (2004) \\
\hline 2003 & July-August & Summer monsoon & $\begin{array}{l}\text { anticyclonic warm gyre: } 1.84 \\
\text { cyclonic eddy: } 5.01 \\
\text { upwelling zone: } 5.2\end{array}$ & & $\begin{array}{l}\text { anticyclonic warm gyre: } \\
\text { negligible } \\
\text { cyclonic eddy: } 163 \\
\text { upwelling zone: } 271\end{array}$ & Muraleedharan et al. (2006) \\
\hline 2003 & September & Summer monsoon & & $0.2-0.35$ & $89.4-220.6$ & Kumar et al. (2010) \\
\hline 2003 & & Fall intermonsoon & & $0.3-0.4$ & $184.14-512.85$ & Kumar et al. (2010) \\
\hline 2003 & $\begin{array}{l}\text { September- } \\
\text { October }\end{array}$ & Post-monsoon & & & $\begin{array}{l}\text { coastal: } 281 \\
\text { oceanic: } 364\end{array}$ & Kumar et al. (2004) \\
\hline 2007 & $\begin{array}{l}\text { November- } \\
\text { December }\end{array}$ & $\begin{array}{l}\text { Pre-/early } \\
\text { winter monsoon }\end{array}$ & & & cyclonic eddy: $203-430$ & Singh et al. (2015) \\
\hline 2010 & & Summer & & & $221.41 \pm 4.97$ & Mohanty et al. (2014) \\
\hline 2010 & & Winter & & & $186.69 \pm 9.87$ & Mohanty et al. (2014) \\
\hline 2010 & & Monsoon & & & $151.25 \pm 2.16$ & Mohanty et al. (2014) \\
\hline 2010 & & Post-monsoon & & & $167.87 \pm 3.02$ & Mohanty et al. (2014) \\
\hline 2014 & January & NE monsoon & & $0.08-0.035$ & $1.4-9.3$ & Löscher et al. (2020) \\
\hline 2014 & March-April & Intermonsoon & & & $182-1261$ (average $936 \pm 350$ ) & Anand et al. (2017) \\
\hline 2018 & March-April & Intermonsoon & $34.6 \pm 4$ & cyclonic eddy $0.35 \pm 0.08$ & $411-920$ & Sarma, et al., 2019 \\
\hline 2018 & March-April & Intermonsoon & $26.4 \pm 4$ & outside eddy $0.22 \pm 0.06$ & & Sarma et al. (2019) \\
\hline 2018 & March-April & Intermonsoon & $23.6 \pm 3$ & $\begin{array}{l}\text { anticyclonic eddy northern } \\
\text { region } 0.11 \pm 0.06\end{array}$ & & Sarma et al. (2019) \\
\hline 2018 & March-April & Intermonsoon & $22.2 \pm 3$ & $\begin{array}{l}\text { anticyclonic eddy southern } \\
\text { region } 0.10 \pm 0.03\end{array}$ & & Sarma et al. (2019) \\
\hline 2018 & July-August & Summer monsoon & 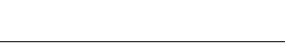 & & $288-1044$ & Saxena et al. (2020) \\
\hline
\end{tabular}




\section{Key primary producers in BoB waters}

Compared to records of primary production, even fewer data on the primary producer community are available, and chlorophyll concentrations are often the only parameter presented (Table 1). Typically, coastal chlorophyll concentrations are about an order of magnitude higher compared to those in the central BoB (e.g., Radhakrishna et al., 1978; Ramaiah et al., 2010; Balachandran et al., 2008; Gauns et al., 2005; Kumar et al., 2010). A detailed glider-based survey in the southern open ocean waters of the BoB recorded chlorophyll distributions with maxima of $0.3-1.2 \mathrm{mg} \mathrm{m}^{-3}$ located at the base of the mixed layer at about 50-60 $\mathrm{m}$ water depth (Thushara et al., 2019). Records of discrete measurements show a comparable distribution for the open waters of the $\mathrm{BoB}$ and in addition an extension of chlorophyll concentrations of up to $0.3 \mathrm{mg} \mathrm{m}^{-3}$ north of $15^{\circ} \mathrm{N}$ possibly connected to riverine nutrient imports (Bhushan et al., 2018; Löscher et al., 2020; $\mathrm{Li}$ et al., 2012). Exemplary vertical profiles of open ocean chlorophyll distributions and a diversity of typically observable primary producers are depicted in Fig. 2 .

Historically available phytoplankton diversity records have methodological limitations relying mostly on direct or microscopic phytoplankton counts; therefore, small-sized phytoplankton and cyanobacteria are likely underrepresented. There is, however, a general consensus in earlier and newer studies that diatoms dominate the pool of primary producers (Gauns et al., 2005; Madhupratap et al., 2003; Devassy et al., 1983), with some historical records being astonishingly detailed, presenting phytoplankton distribution down to the genus and species levels (Nair and Gopinathan, 1983), and their results are comparable to more recent studies (Ramaiah et al., 2010) showing a diversity of diatoms including Thalassiothrix, Nitzschia, Thalassionema, Skeletonema, Chaetoceros, and Coscinodiscus clades being abundant (Devassy et al., 1983; Ramaiah et al., 2010). Diversity analysis based on bulk DNA and amplicon sequencing complemented those previously available datasets by adding a higher diversity of eukaryotic phytoplankton, including Pelagophyceae, Haptophyceae, Chrysophyceae, Eustigamatophyceae, Xanthophyceae, Cryptophyceae, Dictyochophyceae, and Pinguiophyceae and importantly by adding small cyanobacteria, which are difficult to count microscopically and were therefore not included in previous records (Löscher et al., 2020; Yuqiu et al., 2020; Bemal et al., 2019; Larkin et al., 2020; Pujari et al., 2019). Those cyanobacteria accounted for up to $60 \%$ of the primary producer abundance in sequence datasets in the central $\mathrm{BoB}(\mathrm{Li}$ et al., 2012) and include Synechococcus and Prochlorococcus. The former has been detected from the surface down to the chlorophyll maximum, while the latter has been found to be abundant in the lower margin of the chlorophyll maximum at around $50-80 \mathrm{~m}$ water depth, slightly deeper than the maximum of eukaryotic primary producers (Löscher et al., 2020; Yuqiu et al., 2020). The Prochlorococcus popula- tion has been described to consist of several different ecotypes of the HLII clade with their respective abundances being governed by macro- and micronutrient distribution and by temperature (Larkin et al., 2020; Pujari et al., 2019). Similar distributions of Prochlorococcus and Synechococcus have been found in other OMZ areas (Beman and Carolan, 2013; Franz et al., 2012; Meyer et al., 2016), following similar vertical and coast to open ocean patterns. The deeper maximum of Prochlorococcus as a result of its pigment composition adapting to lower light levels (Moore et al., 1998; Rocap et al., 2003) possibly allows for utilization of nutrients from sinking organic matter at the lower boundary of the mixed layer. Metagenomes from the Atlantic have previously demonstrated the genetic potential of Prochlorococcus HLII clades to grow on nitrate (Rusch et al., 2007), supporting the earlier suggestion that some Prochlorococcus ecotypes thrive at the base of the euphotic zone to acquire nitrate from underlying waters (Vaulot and Partensky, 1992; Olson et al., 1990). While there is a body of literature describing distribution patterns of the Prochlorococcus ecotype (e.g., Johnson et al., 2006; Martiny et al., 2009; Moore et al., 1998), the relative contribution of different Prochlorococcus ecotypes to primary production in the ocean is not well resolved. In addition, information on the specific contribution of Prochlorococcus ecotypes detected in the BoB to bulk primary production is not available. Thus, it is unclear whether a change in Prochlorococcus ecotype composition as suggested by Larkin et al. (2019), in response to changing temperatures, nutrient concentration, or iron stress, would correspond to changes in overall Prochlorococcus primary production. A community shift in small cyanobacteria may be somewhat speculative and with unknown impacts on bulk primary production. However, an overall increase in abundance of small cyanobacteria in concert with a decrease in eukaryotic primary producers would be expected to impact $\mathrm{BoB}$ biogeochemistry, especially with regard to the spatial expansion and the intensity of the OMZ through modified export production and respiration in low-oxygen intermediate waters.

Besides those small cyanobacteria, there are reports on nitrogen-fixing cyanobacteria of the Trichodesmium clade (Devassy et al., 1983; Jyothibabu et al., 2017; Sahu et al., 2017; Hegde et al., 2008; Shetye et al., 2013; Wu et al., 2019); other reports included diatom-diazotroph associations playing a role in BoB nitrogen fixation (Bhaskar et al., 2007). However, for both types of nitrogen-fixing primary producers, datasets are not conclusive and indicate high spatial and temporal variability. Nitrogen-fixing microbes have been proposed to be limited by iron, other micronutrients, or organic matter in the BoB (Löscher et al., 2020; Saxena et al., 2020; Shetye et al., 2013; Benavides et al., 2018). While micronutrients would have the potential to also directly limit primary production, a limitation of nitrogen fixers by organic matter would result in a feedback regulation of low primary 


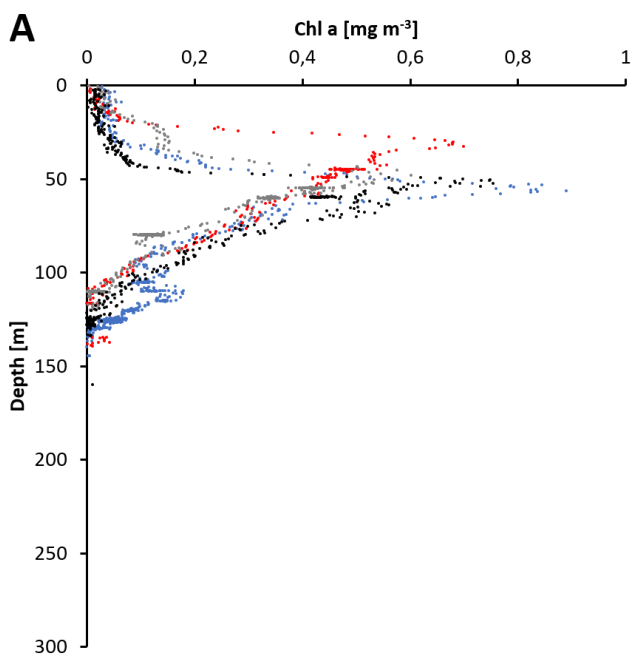

B

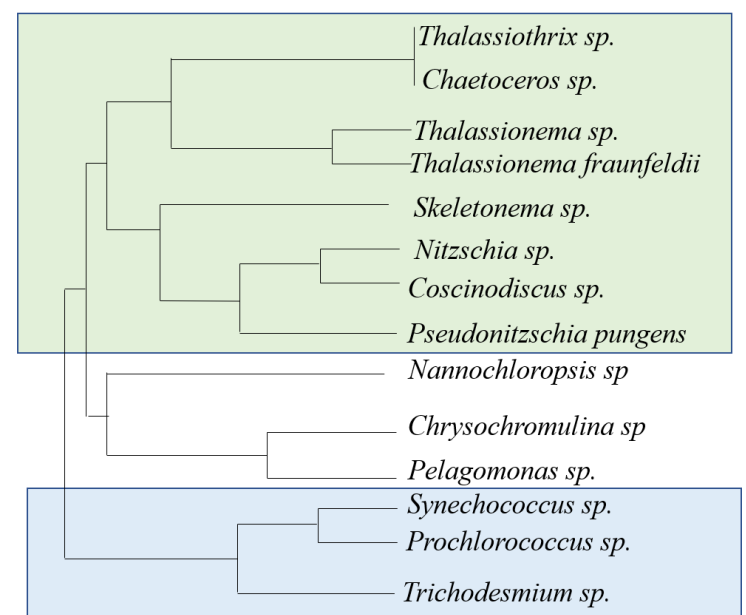

Figure 2. (a) Vertical profiles of chlorophyll $a$ from four stations in the open ocean region of the BoB taken from Löscher et al. (2020). (b) Schematic depiction of the phylogenetic diversity of primary producers identified in the BoB: green box: diatoms; blue box: cyanobacteria.

production limiting nitrogen fixation and resulting low nitrogen availability limiting primary production.

\section{Trends in primary production in the $\mathrm{BoB}$}

Satellite data from 1998 to 2015 suggest a decrease in primary production in the global ocean (Gregg et al., 2003; Behrenfeld et al., 2006), and recent studies deducted a decrease in ocean primary production of $2.1 \%$ per decade associated largely with a decrease in chlorophytes in the marine photic realm (Gregg et al., 2017; Gregg and Rousseaux, 2019). However, a recent study derived a nonlinear trend in primary production from a similar time episode, between 1998 and 2018 (Kulk et al., 2020). Decreasing rates of primary production have been associated with high-latitude regions (Gregg et al., 2003), but also with the northern and equatorial Indian Ocean with a decrease of $9.7 \%$ and $17.2 \%$ per decade, respectively (Gregg and Rousseaux, 2019). These estimates, based on satellite imaging, were explained by a decrease in diatom and chlorophyte primary production of $15.4 \%$ and $24.8 \%$ per decade, respectively, for both the BoB and its sister basin, the Arabian Sea (Fig. 3). This decrease has been connected to decreasing nitrate and silicate concentrations of $32.4 \%$ and $22.8 \%$ per decade in those waters, limiting those larger, fast-growing primary producer groups (Gregg and Rousseaux, 2019), with nitrate rather than silicate limiting primary production if assuming Redfield stoichiometry (Kumar et al., 2010; Radhakrishna et al., 1978). At the same time, an increase in small cyanobacterial primary producers, Prochlorococcus and Synechococcus, was described in this region, with an increase in cyanobacterial primary production of $16.7 \%$ per decade (Gregg and Rousseaux, 2019). Satellite-based imaging indeed showed a southward expansion and increase in abundance of cyanobacteria in the Bay of Bengal and through the southern Arabian Sea (Fig. 3). Molecular genetic data showed, however, that Prochlorococcus is expanding and mostly certain ecotypes of high-light Prochlorococcus increased in abundance and extended their habitat (Larkin et al., 2020). Given the decrease in both nitrate and silicate, a decrease in the silicate-correlated ecotypes currently dominant in the northern BoB would be expected, and those may be replaced by an open ocean ecotype sensitive to increasing iron concentrations in those waters. The overall increase in cyanobacteria derived from satellite monitoring is, however, not provable by direct measurements due to the lack of counts in the earlier reports and further does not seem to impact the overall prediction on primary production decrease.

Qualitatively consistent with the short-term trend of decreasing primary production between 1998 and 2015, a pronounced decrease of up to $20 \%$ in phytoplankton in the western Indian Ocean over the past 6 decades has been ascribed to increasing ocean stratification as a consequence of rapid warming in the Indian Ocean, which suppresses nutrient mixing from subsurface layers (Roxy et al., 2016). This result is indeed consistent with a long-term trend with decreasing productivity since the last glacial maximum (Contreras-Rosales et al., 2016; Shetye et al., 2014). With primary production leading to respiration and a concurrent oxygen loss in intermediate waters, this may provide an explanation for why the $\mathrm{BoB}$ is the only oxygen minimum zone region with traces of oxygen left in its core waters. It has often been suggested that the $\mathrm{BoB}$ is at a tipping point in developing severe anoxia (Bristow et al., 2017; Canfield et al., 2019; Rixen et al., 2020), which is a threshold with only minor changes in bio- 

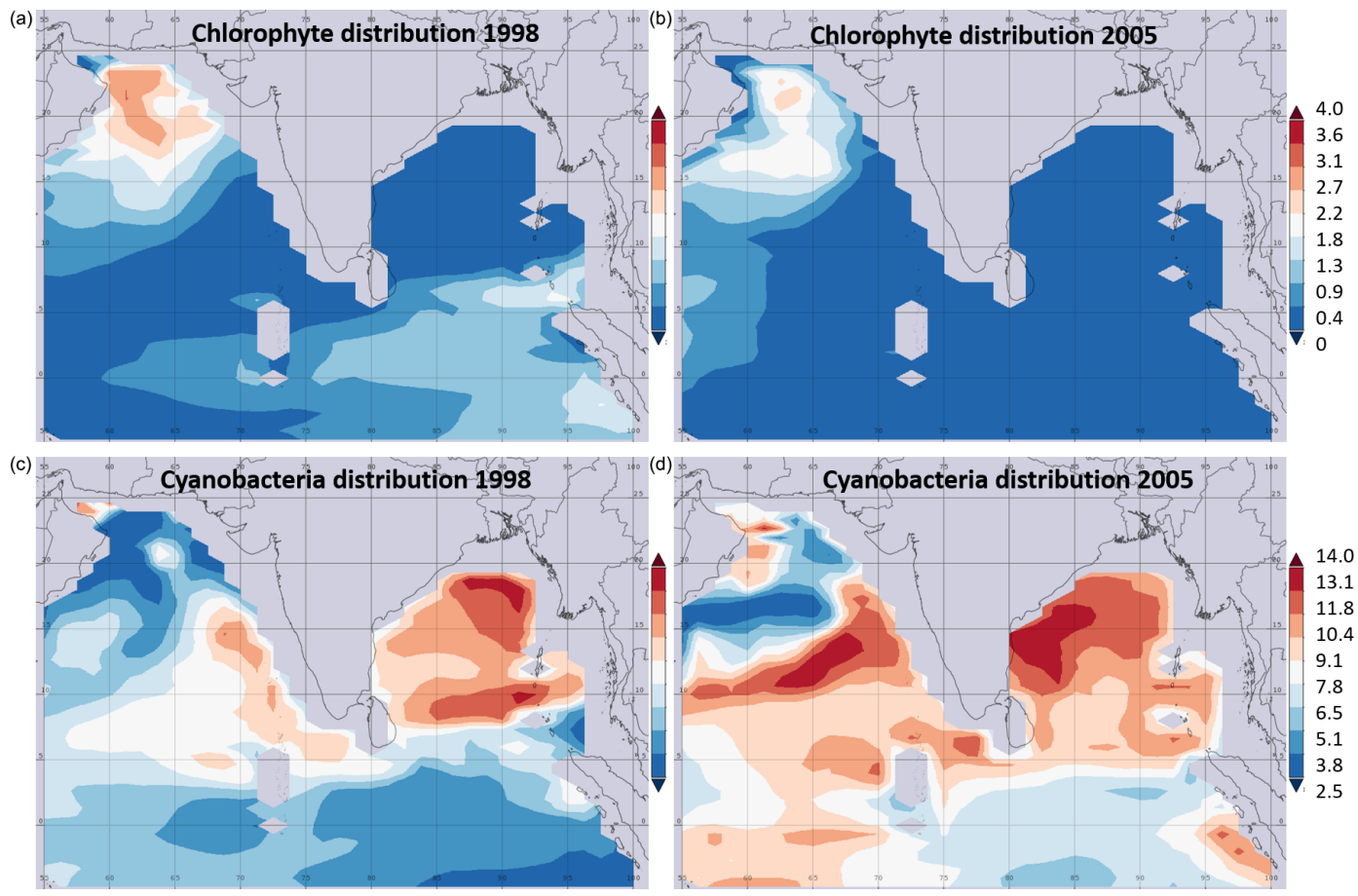

Figure 3. Satellite-imaging-based comparison of chlorophytes (a, b) and cyanobacteria from 1998 and $2015 \mathrm{in} \mathrm{mg} \mathrm{m}^{-3}$. Data obtained from a combination of the Sea-viewing Wide Field of view Sensor (SeaWiFS), the Moderate Resolution Imaging Spectroradiometer (MODISAqua), and the Visible Infrared Imaging Radiometer Suite (VIIRS) satellite product as available from https://giovanni.gsfc.nasa.gov (last access: 12 January 2021) have been averaged from 1 January to 15 December 1998 and 2005. The combination of those sensors allows for covering a range of different wavelengths useful to identify different phytoplankton clades. The maps have been generated using the NASA Ocean Biogeochemical Model (NOBM; Gregg and Casey, 2007) using the most recent version of the NASA ocean color data product (R2014). NOBM is designed to represent open ocean areas (water depths $>200 \mathrm{~m}$ ).

geochemistry leading to a consumption of oxygen traces in the oxygen minimum zone. This scenario is, however, challenged by decreasing primary production on long-term and decadal timescales.

\section{Possible scenarios in response to changes in primary production on the BoB OMZ}

Reports of decreasing primary production in the $\mathrm{BoB}$ available from geological records, Earth system modeling, and satellite imaging are consistent over different timescales. But explanations on why primary production and chlorophyll concentrations decrease differ. Proposed important parameters include iron stress with iron concentrations having decreased in the geological record over the last 5000 years (Shetye et al., 2014), a decrease in nitrate and silicate availability directly impacting primary producer growth (Gregg and Rousseaux, 2019), a rapid temperature increase of $0.6^{\circ} \mathrm{C}$ over the last 6 decades, or a combination of those factors, which may directly or indirectly via increased stratification decrease primary production (Roxy et al., 2016). These considerations cannot clearly be compared and evaluated using the few direct measurements available, as those expose a high temporal and spatial variability. They allow, however, for theoretically exploring what would happen to the $\mathrm{BoB}$ biogeochemistry if nutrient concentrations would decrease further, with the exception of coastal regions, where nitrogen inputs may increase and enter the ocean via rivers but would also at the same time be removed quickly and close to the coast as is currently happening in the BoB (Naqvi et al., 2010), and temperatures would increase.

Assuming a limitation of primary production by nitrogen availability, we would expect a niche for nitrogen fixation developing in the BoB. Until now, nitrogen fixation rates have shown to be low (Löscher et al., 2020; Saxena et al., 2020), and while there were reports on local blooms of the efficient nitrogen fixer Trichodesmium (Shetye et al., 2013), the nitrogen fixer community is dominated by typically less active heterotrophic bacteria (Wu et al., 2019; Turk-Kubo et al., 2014). However, our understanding of the diazotroph community composition and $\mathrm{N}_{2}$ fixation rates is hampered by the low number of available datasets and their spatial and seasonal bias. Nitrogen fixers in general have a high requirement for iron; therefore an iron limitation could ultimately limit nitrogen fixation and indirectly primary production, as discussed earlier (Löscher et al., 2020). A further decrease in 

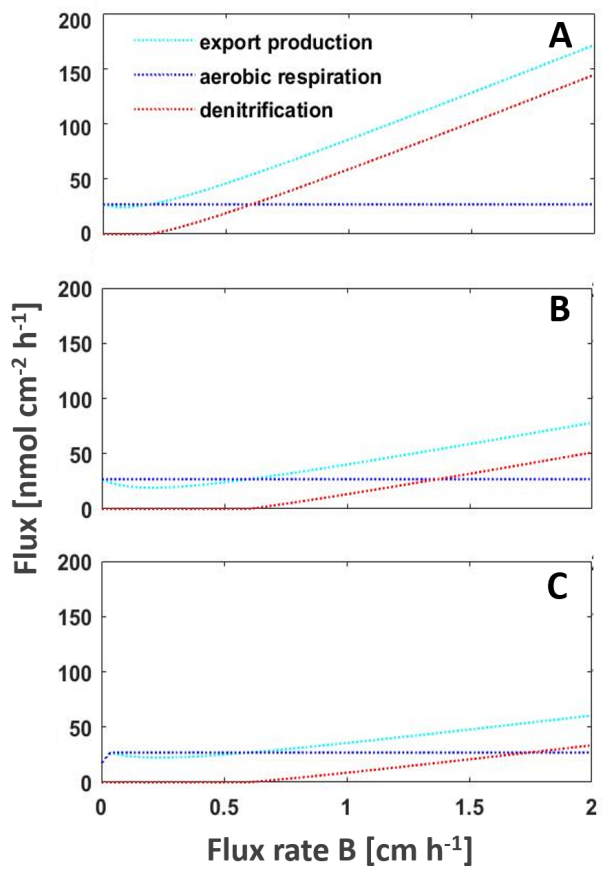

Figure 4. Model of the main processes export production, aerobic respiration, and denitrification shaping the intensity of the BoB OMZ to changing nutrient fluxes from riverine, land, or atmospheric inputs or upwelling to increased upwelling, with (a) current nutrient loads (b) decreasing nitrate concentrations by $32 \%$ as predicted by Gregg et al. (2019) and (c) with both decreased nitrate concentrations and decreased nutrient fluxes from deeper waters as a result of warming-dependent increased stratification. The model is adapted from Boyle et al. (2013).

iron would intensify this limitation and progressive decrease the productivity in the BoB. In addition, a decrease in silicate would limit diatom growth which need silica to form their frustules. Therefore, a combined decrease in iron, nitrate and silicate concentrations will lower primary production of various groups of primary producers at the same time, which may not only explain the trend visible from satellite imaging (Gregg and Rousseaux, 2019) but may allow to predict a future trend for the BoB biogeochemistry.

Our earlier studies presented possible feedback cycles that are able to explain the persistent nanomolar levels of oxygen in the BoB OMZ (Canfield et al., 2019; Löscher et al., 2020). One approach included low mixing levels, or permanent stratification limiting euphotic zone nutrient concentrations to an extent that new production is persistently low and organic matter recycling will not support the organic carbon requirement of the detected heterotrophic nitrogen fixer community. This we suggested to lead the system to being locked in a low productivity and increasingly nitrogen limited scenario with the OMZ increasingly weakening. Applying lower concentrations of nitrate and iron (Fig. 4; silicate is not parameterized in our model but would lead to a similar effect if it would be limiting primary production), we observe that the
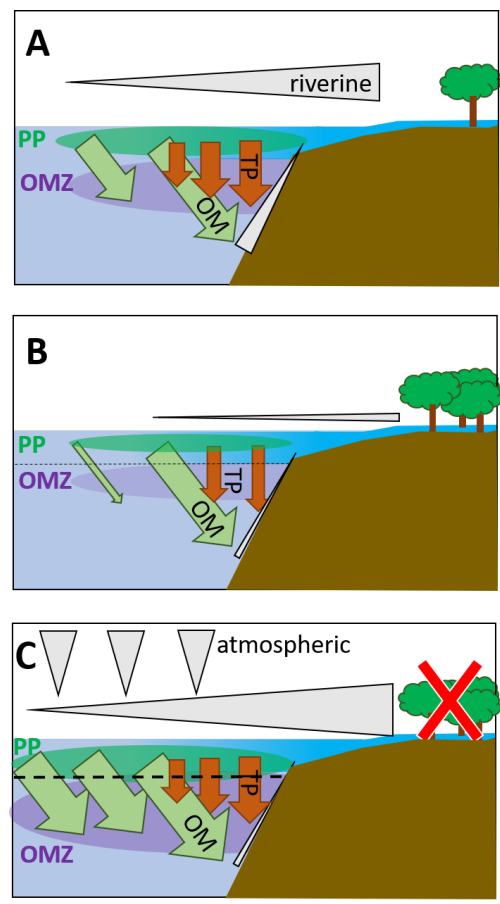

Figure 5. Schematic depiction of fluxes impacting primary production and the oxygen minimum zone in the $\mathrm{BoB}$ (a) during the last glacial maximum (modified from Contreras-Rosales et al., 2016), (b) currently (c) and in a scenario leading to an anoxic OMZ. The latter would require higher nutrient fluxes from the atmosphere, from upwelling, or from rivers and land. Fluxes from land may increase, e.g., from deforestation or enhanced rainfalls; however, higher terrigenous particle load would likely accompany increased nutrient loads, and therefore, even if coastal primary production would increase, export production would increase via ballasting, too. The effect on the OMZ would then be rather small. Upwellingdependent nutrient pumping is unlikely to increase due to warming and enhanced stratification but may occur in particular in eddy systems, i.e., as eddy pumping. Grey triangles depict nutrient fluxes from land and rivers, from upwelling along the shelf, and from the atmosphere. Brown arrows depict terrigenous particle fluxes as imported from rivers and leading to ballasting and enhanced organic carbon export. Green arrows depict organic material exported from the photic zone primary production (green bubble, PP) into the OMZ (purple bubble). Sizes of triangles, arrows, and bubbles qualitatively indicate proportions.

OMZ respiration will lower, low oxygen concentrations will be maintained, and denitrification will only occur if nutrients are imported into the OMZ from land, via rivers, from the atmosphere, or by increased upwelling (Fig. 4). This would mean the BoB may not be at a tipping point towards anoxia but is a system with a weakening OMZ in its open waters, with progressive warming stabilizing this trend by increasing stratification in the photic zone and cutting this part of the water column off any nutrient supply.

Comparing scenarios of primary production and its impact on the $\mathrm{BoB} \mathrm{OMZ}$, the last glacial maximum signi- 
fies an episode of high productivity in the geological record (Contreras-Rosales et al., 2016, Fig. 5a). Higher land runoff and riverine inputs led to both higher nutrient imports and increased loads of terrigenous material, facilitating organic carbon export from the productive zone to the sediments through ballasting. This effect is also currently seen, with nutrients being imported and consumed close to the shelf and organic material exported out of the photic zone (Fig. 5b), leading to a carbon pump with similar export rates as in the Arabian Sea (Singh and Ramesh, 2015). A scenario with production being enhanced would strongly depend on external nutrient inputs; those could come from land and riverine inflow and could for example result from deforestation, enhanced monsoon events, increasing atmospheric input, or enhanced upwelling, which has been described to enhance primary production in (sub-)mesoscale features (Sarma and Udaya Bhaskar, 2018, Fig. 5b). Because global warming will result in increased stratification, enhanced nutrient pumping from deeper waters may be limited to mesoscale eddies, the BoB may be a rather stable system in itself, and the observed and predicted changes in primary producers are not suggestive of a development of anoxia in the BoB OMZ.

Code availability. Code is available from the PANGAEA data repository, https://doi.org/10.1594/PANGAEA.905498 (Boyle, 2019).

Competing interests. The authors declare that they have no conflict of interest.

Disclaimer. Publisher's note: Copernicus Publications remains neutral with regard to jurisdictional claims in published maps and institutional affiliations.

Special issue statement. This article is part of the special issue "Understanding the Indian Ocean system: past, present and future (BG/ACP/OS/SE inter-journal SI)". It is not associated with a conference.

Acknowledgements. I thank Christian Furbo Reeder, Peihang Xu, Jakob Bang Rønning, Jovitha Lincy and Donald Eugene Canfield for helpful discussions on $\mathrm{BoB}$ productivity patterns and the BoB OMZ. I thank Mar Benavides and Arvind Singh for their helpful and constructive reviews.

Financial support. This research has been supported by the Villum Fonden (grant no. 29411).
Review statement. This paper was edited by Viviane Menezes and reviewed by Arvind Singh and Mar Benavides.

\section{References}

Balachandran, K. K., Laluraj, C. M., Retnamma, J., Madhu, N. V., Muraleedharan, K. R., Vijay, J. G., Maheswaran, P. A., Ashraff, T. T. M., Nair, K. K. C., and Achuthankutty, C. T.: Hydrography and biogeochemistry of the north western Bay of Bengal and the north eastern Arabian Sea during winter monsoon, J. Mar Syst., 73, 76-86, https://doi.org/10.1016/j.jmarsys.2007.09.002, 2008.

Behrenfeld, M. J., Randerson, J. T., McClain, C. R., Feldman, G. C., Los, S. O., Tucker, C. J., Falkowski, P. G., Field, C. B., Frouin, R., Esaias, W. E., Kolber, D. D., and Pollack, N. H.: Biospheric Primary Production During an ENSO Transition, Science, 291, 2594-2597, https://doi.org/10.1126/science.1055071, 2001.

Behrenfeld, M. J., O’Malley, R. T., Siegel, D. A., McClain, C. R., Sarmiento, J. L., Feldman, G. C., Milligan, A. J., Falkowski, P. G., Letelier, R. M., and Boss, E. S.: Climate-driven trends in contemporary ocean productivity, Nature, 444, 752-755, https://doi.org/10.1038/nature05317, 2006.

Bemal, S., Anil, A. C., and Amol, P.: Picophytoplankton variability: Influence of Rossby wave propagation in the southeastern Arabian Sea, J. Mar Syst., 199, 103221, https://doi.org/10.1016/j.jmarsys.2019.103221, 2019.

Beman, J. M. and Carolan, M. T.: Deoxygenation alters bacterial diversity and community composition in the oceans largest oxygen minimum zone, Nat. Commun., 4, https://doi.org/10.1038/ncomms3705, 2013.

Benavides, M., Martias, C., Elifantz, H., Berman-Frank, I., Dupouy, C., and Bonnet, S.: Dissolved Organic Matter Influences $\mathrm{N}_{2}$ Fixation in the New Caledonian Lagoon (Western Tropical South Pacific), Front. Mar. Sci., 5, 89, https://doi.org/10.3389/fmars.2018.00089, 2018.

Bhaskar, J. T., Ramaiah, N., Gauns, M., and Fernandes, V.: Preponderance of a few diatom species among the highly diverse microphytoplankton assemblages in the Bay of Bengal, J. Mar. Biol., 152, 63-75, 2007.

Bhattathiri, P. M. A., Devassy, V. P., and Radhakrishna, K.: Primary production in the Bay of Bengal during southwest monsoon of 1978, Mahasagar-Bulletin of the National Institute of Oceanography, 13, 315-323, 1980.

Bhushan, R., Bikkina, S., Chatterjee, J., Singh, S. P., Goswami, V., Thomas, L. C., and Sudheer, A. K.: and Sudheer, A. K.: Evidence for enhanced chlorophyll-a levels in the Bay of Bengal during early north-east monsoon, J. Ocean. Mar. Sci., 9, 15-23, https://doi.org/10.5897/JOMS2017.0144, 2018.

Boyle, R. A.: Code for ancient ocean 5 box model on euxinic/ ferruginous balance and the nitrogen cycle, PANGAEA [data set], https://doi.pangaea.de/10.1594/PANGAEA.905498, 2019.

Boyle, R. A., Clark, J. R., Poulton, S. W., Shields-Zhou, G., Canfield, D. E., and Lenton, T. M.: Nitrogen cycle feedbacks as a control on euxinia in the mid-Proterozoic ocean, Nat. Commun., 4, 1533, https://doi.org/10.1038/ncomms2511, 2013.

Bristow, L. A., Callbeck, C. M., Larsen, M., Altabet, M. A., Dekaezemacker, J., Forth, M., Gauns, M., Glud, R. N., Kuypers, M. M. M., Lavik, G., Milucka, J., Naqvi, S. W. A., Pratihary, A., Revsbech, N. P., Thamdrup, B., Treusch, A. H., and Canfield, 
D. E.: $\mathrm{N}_{2}$ production rates limited by nitrite availability in the Bay of Bengal oxygen minimum zone, Nat. Geosci., 10, 24-29, https://doi.org/10.1038/ngeo2847, 2017.

Canfield, D. E., Kraft, B., Löscher, C. R., Boyle, R. A., Thamdrup, B., and Stewart, F. J.: The regulation of oxygen to low concentrations in marine oxygen-minimum zones, J. Mar. Res., 77, 297324, https://doi.org/10.1357/002224019828410548, 2019.

Contreras-Rosales, L. A., Schefuß, E., Meyer, V., Palamenghi, L., Lückge, A., and Jennerjahn, T. C.: Origin and fate of sedimentary organic matter in the northern Bay of Bengal during the last $18 \mathrm{ka}$, Glob. Planet. Change, 146, 53-66, https://doi.org/10.1016/j.gloplacha.2016.09.008, 2016.

Cui, W., Yang, J., and Ma, Y.: A statistical analysis of mesoscale eddies in the Bay of Bengal from 22-year altimetry data, Ac. Ocean. Sin., 35, 16, https://doi.org/10.1007/s13131-016-0945-3, 2016.

Dandapat, S. and Chakraborty, A.: Mesoscale Eddies in the Western Bay of Bengal as Observed From Satellite Altimetry in 1993-2014: Statistical Characteristics, Variability and ThreeDimensional Properties, IEEE Journal of Selected Topics in Applied Earth Observations and Remote Sensing, 9, 5044-5054, https://doi.org/10.1109/JSTARS.2016.2585179, 2016.

Devassy, V. P., Bhattathiri, P. M. A., and Radhakrishna, K.: Primary production in the Bay of Bengal during August, 1977, Mahasagar-Bulletin of National Institute of Oceanography, 16, 443-447, 1983.

Dähnke, K. and Thamdrup, B.: Nitrogen isotope dynamics and fractionation during sedimentary denitrification in Boknis Eck, Baltic Sea, Biogeosciences, 10, 3079-3088, https://doi.org/10.5194/bg-10-3079-2013, 2013.

Falkowski, P. G., Barber, R. T., and Smetacek, V. V.: Biogeochemical Controls and Feedbacks on Ocean Primary Production, Science, 281, 200-207, 1998.

Franz, J., Krahmann, G., Lavik, G., Grasse, P., Dittmar, T., and Riebesell, U.: Dynamics and stoichiometry of nutrients and phytoplankton in waters influenced by the oxygen minimum zone in the eastern tropical Pacific, Deep-Sea Res. Pt. I, 62, 20-31, 2012.

Gauns, M., Madhupratap, M., Nagappa, R., Retnamma, J., Fernandes, V., Bhaskar, J., and PrasannaKumar, S.: Comparative accounts of biological productivity characteristics and estimates of carbon fluxes in the Arabian Sea and the Bay of Bengal, Deep-Sea Res. Pt. II, 52, 2003-2017, https://doi.org/10.1016/j.dsr2.2005.05.009, 2005.

Gomes, H. R., Goes, J. I., and Saino, T.: Influence of physical processes and freshwater discharge on the seasonality of phytoplankton regime in the Bay of Bengal, Cont. Shelf Res., 20, 313-330, 2000.

Greaser, S. R., Subrahmanyam, B., Trott, C. B., and Roman-Stork, H. L.: Interactions Between Mesoscale Eddies and Synoptic Oscillations in the Bay of Bengal During the Strong Monsoon of 2019, J. Geophys. Res.-Oceans, 125, e2020JC016772, https://doi.org/10.1029/2020JC016772, 2020.

Gregg, W. W., Conkright, M. E., Ginoux, P., O'Reilly, J. E., and Casey, N. W.: Ocean primary production and climate: Global decadal changes, Geophys. Res. Lett., 30, 1809, https://doi.org/10.1029/2003GL016889, 2003.

Gregg, W. W. and Casey, N. W.: Modeling coccolithophores in the global oceans, Deep-Sea Res. Pt. II, 54, 447-477, 2007.
Gregg, W. W., Rousseaux, C. S., and Franz, B. A.: Global trends in ocean phytoplankton: a new assessment using revised ocean colour data, Remote Sens. Lett., 8, 1102-1111, https://doi.org/10.1080/2150704x.2017.1354263, 2017.

Gregg, W. W. and Rousseaux, C. S.: Global ocean primary production trends in the modern ocean color satellite record (1998-2015), Environ. Res. Lett., 14, 124011, https://doi.org/10.1088/1748-9326/ab4667, 2019.

Hegde, S., Anil, A., Patil, J., Mitbavkar, S., Krishnamurthy, V., and Gopalakrishna, V.: Influence of environmental settings on the prevalence of Trichodesmium spp. in the Bay of Bengal, Mar. Ecol. Prog. Ser., 356, 93-101, https://doi.org/10.3354/meps07259, 2008.

Ittekkot, V.: The abiotically driven biological pump in the ocean and short-term fluctuations in atmospheric $\mathrm{CO}_{2}$ contents, Glob. Planet. Change, 8, 17-25, https://doi.org/10.1016/09218181(93)90060-2, 1993.

Johnson, Z. I., Zinser, E. R., Coe, A., McNulty, N. P., Woodward, E. M., and Chisholm, S. W.: Niche partitioning among Prochlorococcus ecotypes along ocean-scale environmental gradients, Science, 311, 1737-1740, https://doi.org/10.1126/science.1118052, 2006.

Jyothibabu, R., Maheswaran, P. A., Madhu, N. V., Asharaf, T. T. M., Gerson, V. J., Haridas, C., Venugopal, P., Revichandran, C., Nair, K. K. C., and Gopalakrishnan, T. C.: Differential response of winter cooling on biological production in the northeastern Arabian Sea and northwestern Bay of Bengal, Curr. Sci., 87, 783-791, 2004.

Jyothibabu, R., Karnan, C., Jagadeesan, L., Arunpandi, N., Pandiarajan, R. S., Muraleedharan, K. R., and Balachandran, K. K.: Trichodesmium blooms and warm-core ocean surface features in the Arabian Sea and the Bay of Bengal, Mar. Poll. Bull., 121, 201-215, https://doi.org/10.1016/j.marpolbul.2017.06.002, 2017.

Jyothibabu, R., Arunpandi, N., Jagadeesan, L., Karnan, C., Lallu, K. R., and Vinayachandran, P. N.: Response of phytoplankton to heavy cloud cover and turbidity in the northern Bay of Bengal, Sci. Rep., 8, 11282-11282, https://doi.org/10.1038/s41598-01829586-1, 2018.

Krishna, M. S., Prasad, M. H. K., Rao, D. B., Viswanadham, R., Sarma, V. V. S. S., and Reddy, N. P. C.: Export of dissolved inorganic nutrients to the northern Indian Ocean from the Indian monsoonal rivers during discharge period, Geochim. Cosmochim. Ac., 172, 430-443, https://doi.org/10.1016/j.gca.2015.10.013, 2016.

Kulk, G., Platt, T., Dingle, J., Jackson, T., Jönsson, B. F., Bouman, H. A., Babin, M., Brewin, R. J. W., Doblin, M., Estrada, M., Figueiras, F. G., Furuya, K., González-Benítez, N., Gudfinnsson, H. G., Gudmundsson, K., Huang, B., Isada, T., Kovač, Ž., Lutz, V. A., Marañón, E., Raman, M., Richardson, K., Rozema, P. D., Poll, W. H. v. d., Segura, V., Tilstone, G. H., Uitz, J., Dongen-Vogels, V. v., Yoshikawa, T., and Sathyendranath, S.: Primary Production, an Index of Climate Change in the Ocean: Satellite-Based Estimates over Two Decades, Remote Sens., 12, 826, https://doi.org/10.3390/rs12050826, 2020.

Kumar, S., Ramesh, R., Sardesai, S., and Sheshshayee, M. S.: High new production in the Bay of Bengal: Possible causes and implications, Geophys. Res. Lett., 31, L18304, https://doi.org/10.1029/2004GL021005, 2004. 
Larkin, A. A., Garcia, C. A., Ingoglia, K. A., Garcia, N. S., Baer, S. E., Twining, B. S., Lomas, M. W., and Martiny, A. C.: Subtle biogeochemical regimes in the Indian Ocean revealed by spatial and diel frequency of Prochlorococcus haplotypes, Limnol. Oceanogr., 65, 220-232, https://doi.org/10.1002/lno.11251, 2020.

Li, G., Lin, Q., Ni, G., Shen, P., Fan, Y., Huang, L., and Tan, Y.: Vertical Patterns of Early Summer chlorophyll $a$ Concentration in the Indian Ocean with Special Reference to the Variation of Deep Chlorophyll Maximum, J. Mar. Biol., 2012, 801248, https://doi.org/10.1155/2012/801248, 2012.

Longhurst, A. R., Sathyendrenath, S., Platt, T., Caverhill, C., and Res., J. P.: An estimat ion of global primary product ion in the ocean from satellite radiometer data, J. Plankton Res., 17, 12451271, 1995.

Löscher, C. R., Mohr, W., Bange, H. W., and Canfield, D. E.: No nitrogen fixation in the Bay of Bengal?, Biogeosciences, 17, 851864, https://doi.org/10.5194/bg-17-851-2020, 2020.

Madhu, N. V., Maheswaran, P. A., Retnamma, J., Sunil, V., Revichandran, C., Thangavel, B., Gopalakrishnan, T. C., and Nair, K. K. C.: Enhanced biological production off Chennai triggered by October 1999 super cyclone (Orissa), Curr. Sci., 82, 1472 $1479,2002$.

Madhu, N. V., Jyothibabu, R., Maheswaran, P., Gerson, V. J., Gopalakrishnan, T., and Nair, K.: Lack of seasonality in phytoplankton standing stock (chlorophyll $a$ ) and production in the western Bay of Bengal, Cont. Shelf Res., 26, 1868-1883, 2006.

Madhupratap, M., Gauns, M., Nagappa, R., PrasannaKumar, S., Muraleedharan, P. M., DeSousa, S. N., Sardessai, S., and Muraleedharan, D. U.: Biogeochemistry of the Bay of Bengal: Physical, chemical and primary productivity characteristics of the central and western Bay of Bengal during summer monsoon 2001, Deep-Sea Res. Pt. II, 50, 881-896, https://doi.org/10.1016/S0967-0645(02)00611-2, 2003.

Mahadevan, A.: The Impact of Submesoscale Physics on Primary Productivity of Plankton, Annu. Rev. Mar. Sci., 8, 161-184, https://doi.org/10.1146/annurev-marine-010814-015912, 2016.

Martiny, A. C., Kathuria, S., and Berube, P. M.: Widespread metabolic potential for nitrite and nitrate assimilation among Prochlorococcus ecotypes, P. Natl. Acad. Sci. USA, 106, 1078710792, https://doi.org/10.1073/pnas.0902532106, 2009.

Meyer, J., Löscher, C. R., Neulinger, S. C., Reichel, A. F., Loginova, A., Borchard, C., Schmitz, R. A., Hauss, H., Kiko, R., and Riebesell, U.: Changing nutrient stoichiometry affects phytoplankton production, DOP accumulation and dinitrogen fixation - a mesocosm experiment in the eastern tropical North Atlantic, Biogeosciences, 13, 781-794, https://doi.org/10.5194/bg-13-781-2016, 2016

Mohanty, S. S., Pramanik, D. S., and Dash, B. P.: Primary Productivity of Bay of Bengal at Chandipur in Odisha,India, Int. J. Sci. Res., 4, 1-13, 2014.

Moore, L. R., Rocap, G., and Chisholm, S. W.: Physiology and molecular phylogeny of coexisting Prochlorococcus ecotypes, Nature, 393, 464-467, https://doi.org/10.1038/30965, 1998.

Muraleedharan, K., Jasmine, P., Achuthankutty, C. T., Revichandran, C., Kumar, P. D., Anand, P., and Rejomon, G.: Influence of basin-scale and mesoscale physical processes on biological productivity in the Bay of Bengal during the summer monsoon, Prog. Ocean., 72, 364-383, 2007.
Murty, V. S. N., Gupta, G. V. M., Sarma, V. V., Rao, B. P., Jyothi, D., Shastri, P. N. M., and Supraveena, Y.: Effect of vertical stability and circulation on the depth of the chlorophyll maximum in the Bay of Bengal during May-June, 1996, Deep-Sea Res. Pt. I, 47, 859-873, 2000.

Nair, P. V. R., Samuel, S., Joseph, K. J., and Balachandran, V. K.: Primary production and potential fishery resources in the seas around India, in: Proceedings of the symposium on "Living resources of the seas around India”, Cochin: Central Marine Fisheries Research Institute, 184-198, 1973.

Nair, P. V. R. and Gopinathan, C. P.: Primary production in coastal waters, CMFRI Bull., 34, 29-32, 1983.

Naqvi, S. W. A., Naik, H., D’Souza, W., Narvekar, P. V., Paropkari, A. L., and Bange, H. W.: Carbon and nitrogen fluxes in the North Indian Ocean, in: Carbon and nutrient fluxes in continental margins: A global synthesis, edited by: Liu, K.-K., Atkinson, L., Quiñones, R., and Talaue-McManus, L., Springer-Verlag, New York, 180-191, 2010.

Nielsen, E. S. and Jensen, E. A.: Primary Oceanic Production: The Autotrophic Production of organic matter in the oceans, in: Galathea Report Copenhagen 1957-9, Library of the National History Museum Copenhagen, 1, 49-136, 1957.

Olson, R. J., Chisholm, S. W., Zettler, E. R., Altabet, M. A., and Dusenberry, J.: Spatial and temporal distributions of prochlorophyte picoplankton in the North Atlantic Ocean, Deep Sea Res. Pt. A, 37, 1033-1051, 1990.

Prasanna Kumar, S., Muraleedharan, P. M., Thoppil, P., Gauns, M., Nagappa, R., De Souza, S. N., Sardesai, S., and Madhupratap, M.: Why Bay of Bengal is less productive during summer monsoon compared to the Arabian Sea?, Geophys. Res. Lett., 29 , 881-884, https://doi.org/10.1029/2002GL016013, 2002.

Prasanna Kumar, S., Narvekar, J., Murukesh, N., Nagappa, R., Sardessai, S., Gauns, M., Fernandes, V., and Bhaskar, J.: Is the biological productivity in the Bay of Bengal light limited?, Curr. Sci., 98, 1331-1339, 2010.

Pujari, L., Wu, C., Kan, J., Li, N., Wang, X., Zhang, G., Shang, X., Wang, M., Zhou, C., and Sun, J.: Diversity and Spatial Distribution of Chromophytic Phytoplankton in the Bay of Bengal Revealed by RuBisCO Genes (rbcL), 10, 1501, https://doi.org/10.3389/fmicb.2019.01501, 2019.

Radhakrishna, K., Devassay, V. P., Bhargava, R. M. S., and Bhattathiri, P. M. A.: Primary production in the Northern Arabian Sea, Ind. J. Mar. Sci., 7, 271-275, 1978.

Ramaiah, N., Fernandes, V., Bhaskar, J., Retnamma, J., Gauns, M., and Jayraj, E. A.: Seasonal variability in biological carbon biomass standing stocks and production in the surface layers of the Bay of Bengal, IInd. J. Mar. Sci., 39, 369-379, 2010.

Rixen, T., Cowie, G., Gaye, B., Goes, J., do Rosário Gomes, H., Hood, R. R., Lachkar, Z., Schmidt, H., Segschneider, J., and Singh, A.: Reviews and syntheses: Present, past, and future of the oxygen minimum zone in the northern Indian Ocean, Biogeosciences, 17, 6051-6080, https://doi.org/10.5194/bg-176051-2020, 2020.

Rocap, G., Larimer, F. W., Lamerdin, J., Malfatti, S., Chain, P., Ahlgren, N. A., Arellano, A., Coleman, M., Hauser, L., Hess, W. R., Johnson, Z. I., Land, M., Lindell, D., Post, A. F., Regala, W., Shah, M., Shaw, S. L., Steglich, C., Sullivan, M. B., Ting, C. S., Tolonen, A., Webb, E. A., Zinser, E. R., and Chisholm, S. W.: Genome divergence in two Prochlorococcus ecotypes 
reflects oceanic niche differentiation, Nature, 424, 1042-1047, https://doi.org/10.1038/nature01947, 2003.

Roxy, M. K., Modi, A., Murtugudde, R., Valsala, V., Panickal, S., Prasanna Kumar, S., Ravichandran, M., Vichi, M., and Lévy, M.: A reduction in marine primary productivity driven by rapid warming over the tropical Indian Ocean, Geophys. Res. Lett., 43, 826-833, https://doi.org/10.1002/2015GL066979, 2016.

Rusch, D. B., Halpern, A. L., Sutton, G., Heidelberg, K. B., Williamson, S., Yooseph, S., Wu, D., Eisen, J. A., Hoffman, J. M., Remington, K., Beeson, K., Tran, B., Smith, H., Baden-Tillson, H., Stewart, C., Thorpe, J., Freeman, J., Andrews-Pfannkoch, C., Venter, J. E., Li, K., Kravitz, S., Heidelberg, J. F., Utterback, T., Rogers, Y.-H., Falcón, L. I., Souza, V., Bonilla-Rosso, G., Eguiarte, L. E., Karl, D. M., Sathyendranath, S., Platt, T., Bermingham, E., Gallardo, V., Tamayo-Castillo, G., Ferrari, M. R., Strausberg, R. L., Nealson, K., Friedman, R., Frazier, M., and Venter, J. C.: The Sorcerer II Global Ocean Sampling Expedition: Northwest Atlantic through Eastern Tropical Pacific, PLOS Biol., 5, e77, https://doi.org/10.1371/journal.pbio.0050077, 2007.

Sabine, C. L., Feely, R. A., Gruber, N., Key, R. M., Lee, K., Bullister, J. L., Wanninkhof, R., Wong, C. S., Wallace, D. W. R., Tilbrook, B., Millero, F. J., Peng, T.-H., Kozyr, A., Ono, T., and Rios, A. F.: The Oceanic Sink for Anthropogenic $\mathrm{CO}_{2}, 16,367-$ 371, https://doi.org/10.1126/science.1097403, Science, 2004.

Sahu, B. K., Baliarsingh, S. K., Lotliker, A. A., Parida, C., Srichandan, S., and Sahu, K. C.: Winter thermal inversion and Trichodesmium dominance in north-western Bay of Bengal, Ocean Sci. J., 52, 301-306, https://doi.org/10.1007/s12601-017-0028-1, 2017.

Sarma, V. V. S. S. and Udaya Bhaskar, T. V. S.: Ventilation of Oxygen to Oxygen Minimum Zone Due to Anticyclonic Eddies in the Bay of Bengal, J. Geophys. Res.-Biogeo., 123, 2145-2153, https://doi.org/10.1029/2018jg004447, 2018

Sarma, V. V. S. S., Chopra, M., Rao, D., Priya, M., Rajula, G., Lakshmi, D., and Rao, V.: Role of eddies on controlling total and size-fractionated primary production in the Bay of Bengal, Cont. Shelf Res., 204, 104186, https://doi.org/10.1016/j.csr.2020.104186, 2020.

Sarmiento, J. and Gruber, N.: Sinks for Anthropogenic Carbon, Phys. Today, 55, 30-36, https://doi.org/10.1063/1.1510279, 2002.

Saxena, H., Sahoo, D., Khan, M. A., Kumar, S., Sudheer, A. K., and Singh, A.: Dinitrogen fixation rates in the Bay of Bengal during summer monsoon, Environ. Res. Commun., 2, 051007, https://doi.org/10.1088/2515-7620/ab89fa, 2020.

Shetye, S. S., Sudhakar, M., Jena, B., and Mohan, R.: Occurrence of Nitrogen Fixing Cyanobacterium Trichodesmium under Elevated $\mathrm{CO}_{2}$ Conditions in the Western Bay of Bengal, Int. J. Ocean., 2013, 350465, https://doi.org/10.1155/2013/350465, 2013.

Shetye, S. S., Sudhakar, M., Mohan, R., and Jena, B.: Contrasting productivity and redox potential in Arabian Sea and Bay of Bengal, J. Earth Sci., 25, 366-370, https://doi.org/10.1007/s12583014-0415-9, 2014.

Singh, A. and Ramesh, R.: Contribution of riverine dissolved inorganic nitrogen flux to new production in the coastal northern Indian Ocean: An assessment, Int. J. Oceanogr., 2011, 1687-9406, https://doi.org/10.1155/2011/983561, 2011.
Singh, A. and Ramesh, R.: Environmental controls on new and primary production in the northern Indian Ocean, Prog. Oceanogr., 131, 138-145, https://doi.org/10.1016/j.pocean.2014.12.006, 2015.

Singh, A., Gandhi, N., and Ramesh, R.: Contribution of atmospheric nitrogen deposition to new production in the nitrogen limlited photic zone of the northern Indian Ocean, J. Geophys. Res., 117, C06004, https://doi.org/10.1029/2011JC007737, 2012.

Singh, A., Gandhi, N., Ramesh, R., and Prakash, S.: Role of cyclonic eddy in enhancing primary and new production in the Bay of Bengal, J. Sea Res., 97, 5-13, https://doi.org/10.1016/j.seares.2014.12.002, 2015.

Snider, R. G.: The Indian Ocean expedition - An international venture, Eos, Transactions American Geophysical Union, 42, 289294, https://doi.org/10.1029/TR042i003p00289, 1961.

Subha Anand, S., Rengarajan, R., Sarma, V. V. S. S., Sudheer, A. K., Bhushan, R., and Singh, S. K.: Spatial variability of upper ocean POC export in the Bay of Bengal and the Indian Ocean determined using particle-reactive 234Th, J. Geophys. Res.-Oceans, 122, 3753-3770, https://doi.org/10.1002/2016JC012639, 2017.

Subramanian, V.: Sediment load of Indian rivers, Curr. Sci., 64, 928-930, 1993.

Thushara, V., Vinayachandran, P. N. M., Matthews, A. J., Webber, B. G. M., and Queste, B. Y.: Vertical distribution of chlorophyll in dynamically distinct regions of the southern Bay of Bengal, Biogeosciences, 16, 1447-1468, https://doi.org/10.5194/bg-161447-2019, 2019.

Turk-Kubo, K. A., Karamchandani, M., Capone, D. G., and Zehr, J. P.: The paradox of marine heterotrophic nitrogen fixation: abundances of heterotrophic diazotrophs do not account for nitrogen fixation rates in the Eastern Tropical South Pacific, Environ Microbiol., 16, 3095-3114, https://doi.org/10.1111/1462$2920.12346,2014$.

Vaulot, D. and Partensky, F.: Cell cycle distributions of prochlorophytes in the north western Mediterranean Sea, 39, 727-742, 1992.

Vidya, P. J. and Prasanna Kumar, S.: Role of mesoscale eddies on the variability of biogenic flux in the northern and central Bay of Bengal, J. Geophys. Res.-Oceans, 118, 5760-5771, https://doi.org/10.1002/jgrc.20423, 2013.

Vimal Kumar, K., Jayalakshmi, K., Sajeev, R., and Gupta, G.: Role of Mesoscale Eddies in the Distribution Pattern of Zooplankton Standing Stock of Western Bay of Bengal During Spring Transition, J. Mar. Biol. Oceanogr., 5, https://doi.org/10.4172/23248661.1000150, 2016.

Wu, C., Kan, J., Liu, H., Pujari, L., Guo, C., Wang, X., and Sun, J.: Heterotrophic Bacteria Dominate the Diazotrophic Community in the Eastern Indian Ocean (EIO) during Pre-Southwest Monsoon, Microb. Ecol., 78, 804-819, https://doi.org/10.1007/s00248-019-01355-1, 2019.

Yuqiu, W., Xiangweic, Z., Zhao, Y., Huang, D., and Sun, J.: Biogeographic variations of picophytoplankton in three contrasting seas: the Bay of Bengal, South China Sea and Western Pacific Ocean, Aquat. Microb. Ecol., 84, 91-103, https://doi.org/10.3354/ame01928, 2020. 